\title{
Ouers se dissiplinering van vyf- tot sesjariges
}

\begin{tabular}{|c|c|}
\hline \multicolumn{2}{|c|}{$\begin{array}{l}\text { Authors: } \\
\text { Margaret C. Rossouw }{ }^{1} \\
\text { Izak J. Oosthuizen }{ }^{2}\end{array}$} \\
\hline \multicolumn{2}{|c|}{$\begin{array}{l}\text { Affiliations: } \\
{ }^{1} \text { Faculty of Education, } \\
\text { North-West University, } \\
\text { Potchefstroom Campus, } \\
\text { South Africa }\end{array}$} \\
\hline \multicolumn{2}{|c|}{$\begin{array}{l}{ }^{2} \text { Faculty of Education, North- } \\
\text { West University, Mafikeng } \\
\text { Campus, South Africa }\end{array}$} \\
\hline \multicolumn{2}{|c|}{$\begin{array}{l}\text { Correspondence to: } \\
\text { Margaret Rossouw }\end{array}$} \\
\hline \multicolumn{2}{|c|}{$\begin{array}{l}\text { Email: } \\
\text { margaret.rossouw@nwu. } \\
\text { ac.za }\end{array}$} \\
\hline \multicolumn{2}{|c|}{$\begin{array}{l}\text { Postal address: } \\
\text { Private Bag X6001, } \\
\text { Potchefstroom 2520, } \\
\text { South Africa }\end{array}$} \\
\hline \multicolumn{2}{|c|}{$\begin{array}{l}\text { Dates: } \\
\text { Received: } 06 \text { Nov. } 2012 \\
\text { Accepted: } 29 \text { July } 2013 \\
\text { Published: } 04 \text { Dec. } 2013\end{array}$} \\
\hline \multicolumn{2}{|c|}{$\begin{array}{l}\text { How to cite this article: } \\
\text { Roussouw, M.C. \& } \\
\text { Oosthuizen, I.J., 2013, 'Ouers } \\
\text { se dissiplinering van vyf- tot } \\
\text { sesjariges', Koers - Bulletin } \\
\text { for Christian Scholarship } \\
78(3), \text { Art. \#440, } 9 \text { pages. } \\
\text { http://dx.doi.org/10.4102/ } \\
\text { koers.v78i3.440 }\end{array}$} \\
\hline \multicolumn{2}{|c|}{$\begin{array}{l}\text { Copyright: } \\
\text { (C) 2013. The Authors. } \\
\text { Licensee: AOSIS } \\
\text { OpenJournals. This work } \\
\text { is licensed under the } \\
\text { Creative Commons } \\
\text { Attribution License. }\end{array}$} \\
\hline \multicolumn{2}{|l|}{ Read online: } \\
\hline 口itra & $\begin{array}{l}\text { Scan this QR } \\
\text { code with your } \\
\text { smart phone or } \\
\text { mobile device } \\
\text { to read online. }\end{array}$ \\
\hline
\end{tabular}

Die ouerhuis is die basis van ontwikkeling in die voorskoolse jare en ouerskapsvaardighede is daarom van kardinale belang vir die voorkoming van gedragsprobleme wat die kind se toekoms negatief kan beïnvloed. Hierdie artikel rapporteer oor navorsing wat gedoen is om 'n groep Suid-Afrikaanse ouers se menings te ontleed rakende die gedrag van vyf- tot sesjariges wat hulle as problematies ervaar, asook die effek van sodanige gedrag op die ouers, die strategieë wat die ouers toepas, sowel as die aard van die ondersteuning wat hulle verlang. Die konseptueel-teoretiese raamwerk waarin die ondersoek ingebed is, omlyn die konstruk van sosio-emosionele vaardigheidsontwikkeling, die ouer se rol daarin en 'n beskouing van die dissiplinering van die vyf- tot sesjarige kind vanuit 'n bio-ekologiese perspektief (soos gepostuleer deur Bronfenbrenner) met 'n gepaardgaande kritiese inspeling vanuit die Christelike lewensbeskouing.

Parents' disciplining of five to six-year-old children. The home is the basis of development in the preschool years and parenting skills are therefore crucial for the prevention of behaviour that can negatively affect the child's future. This article reports on research conducted through the analysis of the opinions of a group of South African parents regarding the behaviour of their five to six-year-old children that they experienced as being problematic, as well as the effect of the behaviour on the parents, the strategies that they applied, and the nature of the support that they chose. The conceptual-theoretical framework in which the research was embedded explains the construct of socio-emotional development, the parent's role therein and understanding the disciplining of the five to six-year-old child from a bio-ecological perspective (as postulated by Bronfenbrenner) with an accompanying critical perspective from the Christian worldview.

\section{Inleiding}

In die eerste ses jaar van die kind se lewe het die primêre versorgers die grootste impak op die kind se ontwikkeling (Tardiff 2012:15). Hierdie impak word grootliks bepaal deur die ouers se verhouding met die kind, in watter mate in die kind se behoeftes voorsien word en wat die aard van die leiding is wat die kind van die ouers ontvang. Dissiplinering kan beskou word as 'n deel van die leiding wat die ouers aan hulle kinders gee.

Die gedrag van die vyf- tot sesjariges wat deur hulle ouers as problematies beleef word, kom algemeen voor (Joachim, Sanders \& Turner 2010:47). 'n Kanadese ondersoek het bevind dat ongeveer $30 \%$ van twee- tot sesjarige kinders identifiseerbare gedragsprobleme openbaar wat hulle ontwikkeling negatief kan beïnvloed (Russell et al. 2011). Vroeë ingryping in sodanige gedrag deur die ouers, die opvoeders of die terapeute is volgens Chen (2008:472) noodsaaklik om gesonde ontwikkeling vir jong kinders te verseker.

Die ingryping rakende jong kinders se gedrag sluit volgens Oosthuizen $(2006: 32,73)$ voorkomende en afwerende maatreëls in. 'n Benadering waarin aan die kind spesifieke sosiaal-emosionele vaardighede geleer word, kan as voorkomend beskou word, aangesien die ontwikkeling van onaanvaarbare gedrag op hierdie wyse grootliks voorkom kan word.

\section{Probleemstelling}

Die doel van dissiplinering in die voorskoolse jare is onder andere om sosiaal-emosionele vaardighede aan te leer. Daarmee word die volle benutting van die voorskoolse programme soos graad $\mathrm{R}$ verseker en die voorbereiding vir en die aanpassing in graad 1 moontlik gemaak. Vyf- tot sesjariges bevind hulle dikwels in graad R-klasse waar skoolgereedmaking beoog word. Volgens Davin en Van Staden (2005:5) verwys skoolgereedheid na leergereedheid. Dit sluit nie net kognitiewe vermoëns in nie, maar dit vereis ook sosiale en emosionele vaardighede. Denham 
et al. (2012:247) toon aan dat navorsers dit eens is dat sosiaalemosionele vaardighede ' $n$ kind se sukses of mislukking op akademiese en sosiale gebied kan voorspel. Sosiaal-emosionele vaardighede sluit die uitdrukking en regulering van positiewe en negatiewe emosies in, sowel as die deelname binne die sosiale milieu, gefokusde betrokkenheid by die leerprogram en positiewe interaksie met maats en ander mense.

Hoewel aanvaar kan word dat alle ouers hulle jong kinders ten beste wil voorberei op die lewe, bewys die hoë voorkoms van ongedissiplineerde gedrag en die gebrekkige sosio-emosionele vaardighede by vyf- tot sesjariges in graad R-klasse (Keating \& Rossouw 2009) egter dat daar faktore teenwoordig is wat hierdie strewe nadelig beïnvloed. Cowen (2001) toon aan dat gebrekkige kennis van kinderontwikkeling en onvoldoende ouerskapsvaardighede bydra tot die risiko van onaanvaarbare ouerskapspraktyke soos mishandeling en emosionele verwaarlosing. Kinders wat aan swak ouerskapshantering blootgestel word, het 'n vier keer groter kans om emosionele en gedragsprobleme te ontwikkel as kinders wat goeie ouerskapshantering geniet (Sanders et al. 2008). Navorsing toon verder dat negatiewe gedragsuitkomste vir kinders in alle huise kan voorkom, hoewel laer inkomstegroepe 'n groter risiko kan loop dat dit nie gebeur nie (McCain, Mustard \& Shanker 2007).

Ander faktore wat sosio-emosionele vaardigheidsontwikkeling negatief kan beïnvloed, is onder andere hoë stresvlakke in die gesin. Dit kan emosionele ondersteuning vir kinders demp (Duncan \& Brooks-Gunn 1997). Enkelouerstatus, 'n lae onderwyspeil van die moeder, 'n gebrek aan roetines in die huis en die blootstelling aan 'n gevaarlike woonbuurt is voorbeelde van omstandighede wat sosio-emosionele leer kan bemoeilik (Ackerman et al. 1999).

Die tydperk voor ' $n$ kind formele onderrig in graad 1 moet ontvang, bly 'n vensterperiode van waardevolle geleenthede waarin gesonde sosio-emosionele leer bevorder en interpersoonlike vaardighede en gedragsregulering ontwikkel moet word (Sheridan et al. 2010:126). Pearl (2009:295) onderstreep die noodsaaklikheid daarvan dat gebrekkige sosio-emosionele vaardighede en aanvaarbare gedrag vroeg ontwikkel moet word, aangesien die gebrekkige ontwikkeling kan voortduur en die hele gesin negatief kan beïnvloed. Hierin speel die ouer 'n onvervangbare rol. Volgens Schulze en Dzivhani (2002:129) is die mees effektiewe meganisme om gedragsprobleme aan te pak om ouers op te lei in dissiplineringstrategieë en sodoende positiewe ouerskap te bevorder. Positiewe ouerskap behels volgens Tardiff (2012:15) warm en konsekwente interaksies tussen ouers en kinders, waartydens die ouers dikwels met hulle kinders gesels, speel en lag, hulle prys en spesiale dinge saam met die kinders doen. Daar is ook duidelike, konsekwente verwagtings van elke kind asook nie-bestraffende gevolge rakende die gedrag van elke kind. Hierdie benadering sluit aan by Rogers (2006) se mening dat positiewe dissiplinering die effektiefste is.

Baie navorsing is internasionaal op die gebied van ouers se dissiplinering van voorskoolse kinders gedoen (Alegre
2011; Denham et al. 2012; Herrera \& Little 2005; Sheridan et al. 2010). 'n Internetsoektog deur middel van Google Scholar-, EBSCO-host- en ERIC-soekenjins kon egter geen studie opspoor wat spesifiek gefokus is op Suid-Afrikaanse ouers van kinders wat in graad $\mathrm{R}$ is en vir die eerste keer skool toe gaan nie. Hierdie artikel rapporteer oor navorsing wat gedoen is om 'n groep Suid-Afrikaanse ouers se menings rakende gedrag wat hulle as problematies ervaar, die strategieë wat hulle toepas, sowel as die aard van die ondersteuning wat hulle verkies, te ontleed. Die bevindings wat daaruit voortvloei, behoort ' $n$ aanduiding te wees van die aard van die programme wat via die skool in die SuidAfrikaanse konteks vir ouers aangebied kan word.

Die konseptueel-teoretiese raamwerk waarin die ondersoek ingebed is, word in die volgende afdeling aangebied. Dit omlyn die konstruk van sosio-emosionele vaardigheidsontwikkeling, die ouer se rol daarin en 'n beskouing van dissiplinering vanuit 'n bio-ekologiese perspektief (soos gepostuleer deur Bronfenbrenner), met 'n gepaardgaande kritiese inspeling vanuit die Christelike lewensbeskouing. Daarna word 'n uiteensetting gegee van die empiriese ondersoek wat uitgevoer is. Die artikel word afgesluit met ' $n$ uiteensetting van die bevindings, 'n bespreking daarvan en 'n aantal aanbevelings.

\section{Konseptueel-teoretiese raamwerk}

Volgens die Christelike lewensbeskouing geld 'n rangorde van waardes (Afrikaanse Reformatoriese Skoolonderwys [ARSO] 2002), wat die eer van God en liefde vir die medemens tot die hoogste waarde verhef. 'n Belangrike kenmerk van hierdie lewensbeskouing is gehoorsaamheid aan Bybelse norme wat die individu uit dankbaarheid navolg. Ouers is kragtens die norme wat in Deuteronomium 6:7 gestel is verantwoordelik vir die opvoeding van hulle kinders, wat as uniek geskape persone met talente (Matt 25:14-30) beskou word. Ouers benut die waarhede van die Bybel (Deut 4:9; Ps 78:3-7) in die kinderopvoeding sodat die kinders hulle gawes in diens van die medemens en God kan aanwend (ARSO 2002:21). Ouers kom hierdie verpligting egter nie in 'n lugleegte na nie. Die dissiplinering van vyftot sesjarige kinders deur hulle ouers kan daarom ook vanuit Bronfenbrenner (Bronfenbrenner \& Morris 1998, 2006) se bioekologiese teorie beskou word. Al vier essensiële elemente van Bronfenbrenner se teorie, naamlik die proksimale prosesse, die persoon, die konteks en die tyd in die ontwikkeling van die kind word hierby erken. Die dissiplinering deur die ouers word verbind met die impak van al hierdie elemente. Die tydsaspek verwys na die spesifieke tyd in die kinders se lewens, naamlik wanneer hulle in graad $R$ vir die eerste keer skool toe gaan.

Die konteks in Bronfenbrenner se teorie sluit mikrosisteme in soos die direkte gesinsomgewing, die maats en die skoolomgewing. Die wisselwerking tussen die huis en die skool is 'n voorbeeld van 'n mesosisteem. Eksosisteme verwys onder meer na die kind se skoolomgewing, waarin die ouer nie teenwoordig is nie, maar wat 'n direkte invloed op die kind kan hê. Indien die dissiplineringstyl van die 
kind se onderwyser drasties van die ouer s'n verskil, kan dit tot spanning by die huis lei. Bronfenbrenner beskou die makrosisteem as 'n kultuur- of subkultuurkonteks, waarin die lede waardes of geloofsoortuigings, lewenstyle, sosiale interaksiepatrone, gevare, lewensopvattings en lewensbronne deel. Die makrosisteem omsluit al die ander sisteme, beïnvloed die ander sisteme en word ook daardeur beïnvloed (Tudge et al. 2009:208).

Tudge et al. (2009:204) verduidelik dat die proksimale proses in Bronfenbrenner se teorie die verband is tussen 'n aspek van die konteks of 'n aspek van die individu en 'n spesifieke ontwikkelingsuitkoms. Die ontwikkelingsuitkoms is die mate van sukses wat die ouers behaal om die kind sosiale en emosionele vaardighede aan te leer, oftewel om gedissiplineerd op te tree. Die persoonelement is die ouers wat by die dissiplinering van die vyf- tot sesjarige kinders betrokke is. Die eienskappe van die kind, byvoorbeeld temperament, word ook hierby in ag geneem.

Die proksimale proses word gekonseptualiseer as die dissiplineringstrategieë wat tydens die interaksie tussen die volwassene en die kind aangewend word en dit word beïnloed deur die eienskappe van die ouer sowel as die omgewing. Die voortdurende interaksie tussen die kind en die ouer het 'n groter impak op die kind se ontwikkeling as enige ander element. Daar is dus juis daarop gefokus in die navorsing waaroor hier gerapporteer word.

Die interaksie tussen ouers en kinders sluit dissiplineringstrategieë in. 'n Dissiplineringstrategie word gesien as 'n leerproses met handelings wat daarop gemik is om die kinders tot meer verantwoordelike besluitneming te lei. Kinders moet ook leiding kry ten opsigte van die aanvaarding van die gevolge van hulle keuses (Joubert \& Serekwane 2009:134) en die aanleer van sosiaal-aanvaarbare optrede soos beter beheer oor hulle emosies en samewerking in 'n groep. Sosio-emosionele vaardigheidsontwikkeling word met dissiplinestrategieë verbind, aangesien die ouer deur leidinggewing, wat dissiplinering insluit, vir die kind vaardighede op sosiale- en emosionele gebied aanleer.

\section{Sosiaal-emosionele vaardigheidsontwikkeling}

Denham et al. (2012:247) beskryf die sosiaal-emosionele vaardighede wat tydens die kleuterjare aangeleer moet word soos volg: individue moet bewus wees van hulle gevoelens en weet hoe om hulle gepas uit te druk. Positiewe emosies kan aangewend word in die stigting en uitbouing van verhoudings met maats en volwassenes. Negatiewe emosies moet gereguleer word sodat hulle nie die interaksie met ander belemmer nie. Sheridan et al. (2010:147) voeg die volgende vaardighede by: inisiatiefneming, assertiewe optrede en die vermoë om aan te hou probeer om 'n sosiaalemosionele vaardigheid baas te raak ten spyte van frustrasie.

Dit is belangrik om daarop te let dat alle vaardighede oor tyd aangeleer en verfyn word. Sosiaal-emosionele vaardighede is hierby geen uitsondering nie. Daarbenewens moet die wesensaard van die vyf- tot sesjariges in ag geneem word.
Klein kinders leer die beste in 'n omgewing waar hulle geliefd is en 'n ervaring om aan iemand te behoort ondervind. Herhaling, praktiese voorbeelde soos modellering deur die emosioneel-belangrike volwassene (ouer), en positiewe versterking is ook positiewe leerstimulante. Vogel (2008:16) wys ook op die belangrikheid van kommunikasie in taal wat vir kinders verstaanbaar is, sodat die aard van die vaardigheid waarin hulle ingelei word, begryp kan word.

\section{Die ouer se rol in die kind se sosiaal-emosionele vaardigheidsontwikkeling}

Die ouer is die primêre opvoeder en die huisomgewing is die eerste sisteem (mikrosisteem) waarmee die kind in aanraking kom. 'n Stewige ouer-kindverhouding vorm die basis van sekuriteit vir die kind en word volgens Landry et al. (2001) gekenmerk deur warmte, sensitiwiteit vir die kind se behoeftes, emosionele beskikbaarheid vir die verhouding met die kind en ondersteuning vir en aktiewe strukturering van die ontluikende onafhanklikheid. Vanuit die Christelike lewensbeskouing is dit belangrik dat ouers in hulle verhouding met die kind in liefde en met die beste uitkoms vir die kind voor oë optree.

Louw en Louw (2007:194) beskryf Baumrind (1971) se vier dimensies van gesinsfunksionering, naamlik warmte en koestering, duidelikheid en konsekwentheid, verwagtings en kommunikasie. Ouers wat warmte en versorging teenoor die kind toon, skep meer geborge-gehegtheid as ouers wat koud en afsydig optree. Ouerlike warmte kan 'n buffer vorm teen die nadelige gevolge van armoede en 'n gevaarlike omgewing (Bronfenbrenner se makrosisteem). Wanneer ouers met kinders ooreenkom rakende duidelike reëls en dit konsekwent toepas, word sekuriteit versterk en gehoorsaamheid bevorder. Oormatige beperkings ten opsigte van die kind se optrede kan tot oormatige afhanklikheid, moedeloosheid of weerstand lei.

Vanuit 'n Christelike perspektief word hierdie sienswyse in Efesiërs 6 bevestig wanneer oordrewe strengheid afgewys word. Die woord teerheid (tenderly), wat ouers se onderrig en lering beskryf, beklemtoon dissiplinering wat nie kinders krenk, hulle woede laat ontvlam, hulle frustreer of moedeloos maak nie.

Gesinsdimensies sluit nóú aan by ouerskapstyle. Ouers kan moontlik onbewus hiervan wees, maar dit skep 'n opvoedingsklimaat in die huis. Die breër omgewing met sy bepaalde omstandighede, byvoorbeeld die politieke en ekonomiese klimaat (Bronfenbrenner se makrosisteem), beïnvloed ouers se ouerskapstyle (Bronfenbrenner se persoon-element).

\section{Ouerskapstyle}

Vier ouerskapstyle is uit die literatuur bekend, naamlik die outoritêre styl, die outoritatiewe of gesagsbepalende styl, die permissiewe en die verwaarlosende styl (Alegre 2011:57). Outoritêre ouers stel hoë eise aan hulle kinders en oefen streng kontrole uit, maar toon min koestering en kommunikeer nie dikwels met die kinders nie. Hierdie styl 
is volgens Brittz (2009) gebaseer op die oortuiging dat ouers alles weet en dat kinders 'gesien en nie gehoor' moet word nie. Outoritêre ouers verwag onmiddellike gehoorsaamheid en laat nie vrae of onderhandeling toe nie (Firmin \& Castle 2008:119). Die outoritêre ouerskapstyl kan beperkend op die sosio-emosionele vaardigheidsontwikkeling inwerk, aangesien daar min kommunikasie plaasvind en ouers krities en verwerpend kan optree. Indien kinders nie gehoorsaam is nie, kan hierdie ouers hulle tot afjak, skree en vernedering wend. Angstigheid, woede en uittarting kan as gevolg hiervan by die kinders voorkom, sowel as oormatige afhanklikheid van die ouers (Louw \& Louw 2007).

Die outoritatiewe of gesagsbepalende ouerskapstyl word gekenmerk deur warmte en sensitiwiteit, hoë maar ontwikkelingsgerigte verwagtings van die kind, die stel van perke en die beheer van gedrag wanneer dit nodig is, asook liefdevolle, effektiewe kommunikasie. In teenstelling met outoritêre ouers laat outoritatiewe ouers dialoog toe, hulle verduidelik die redes vir beperkings en die gevolge van die kind se optrede en onderhandelings oor aangeleenthede kan ook voorkom (Firman \& Castle 2008:119). Hierdie styl is hoog in al vier dimensies van gesinsfunksionering (Bronfenbrenner) en word volgens Louw en Louw (2007) met 'n positiewe instelling by die kind verbind, asook sosiale samewerking en beheer van emosies, taakvolharding en goeie prestasie op skool. Outoritatiewe ouerskap hou verband met positiewe ouerskap.

Permissiewe ouers stel min eise aan hulle kinders, oefen min beheer uit en is baie liefdevol en aanvaardend (Louw \& Louw 2007). Hierdie styl is dus hoog in koestering, maar laag in al drie die ander dimensies van gesinsfunksionering. Die warmte en aanvaarding wat in oortoegeeflikheid na vore kom, vergoed nie vir die afwesigheid van betrokkenheid, verwagtings en beheer nie. Die kinders van hierdie tipe ouers ontvang ook nie konsekwente terugvoer ten opsigte van hulle gedrag nie (Firmin \& Castle 2008:119). Dit kan hulle sosio-emosionele vaardigheidsontwikkeling strem. Louw en Louw (2007) is van mening dat, aangesien hierdie ouers se kinders dikwels gedwing word om hulle eie besluite te neem oor aspekte waarvoor hulle nog nie gereed is nie, hulle moontlik impulsief, veeleisend, opstandig en ongehoorsaam kan wees.

Onbetrokke, verwaarlosende ouers stel min eise en verwagtings aan hulle kinders, oefen min beheer uit, toon min liefde en kommunikeer nie dikwels nie. Volgens Louw en Louw (2007) kan sodanige ouers omgewingsinvloede of persoonlike probleme as oorweldigend ervaar en emosioneel afsydig teenoor die kinders optree. Aan die ander kant kan meer opwindende aktiwiteite die ouer se energie en tyd in so ' $n$ mate in beslag neem dat die kind se sosio-emosionele vaardigheidsontwikkeling aan die skool of die versorger oorgelaat word. Jewell en Stark (2003) toon aan dat kinders wat later wangedrag toon, dikwels uit huise kom waar ouers onbetrokke en verwaarlosend opgetree het.

Die Bybel verwys in 1 Samuel 2 na Eli as 'n onbetrokke ouer. In 'n bespreking van hierdie Skrifgedeelte word daarop gewys dat Eli nie behoorlik tyd ingeruim het om sy seuns te dissiplineer nie. Sy lewe was op sy bediening van ander mense gerig, terwyl sy eie gesin verwaarloos is. Hierdie benadering het negatiewe gevolge gehad: Eli het sy aansien verloor, sy nering, sy twee seuns en uiteindelik sy eie lewe (Maxwell 2007:325).

Firmin en Castle (2008:120) verbind ouerskapstyle met die gebruik van lyfstraf en toon aan dat lyfstraf in die konteks van al die ouerskapstyle aangewend kan word. Permissiewe ouers kan kinders uit woede impulsief of uit desperaatheid slaan wanneer kinders wat aan hulself oorgelaat is, onbeheerbaar raak. Indien daar nie kontrole is nie, kan outoritêre ouers lyfstraf sodanig toepas dat dit die kind kan beseer. Vanuit 'n Bybelse perspektief in Spreuke 20 en 22 word lyfstraf wel bestempel as 'n wenslike metode vir die hantering van onaanvaarbare kindergedrag. Onbuigsame en rigiede, dogmatiese oortuigings kan egter veroorsaak dat hierdie tipe ouers Bybelse beginsels op 'n ongesonde manier toepas. Firmin en Castle meen dat die gesagsbepalende ouer, met die beste belange van die kind as maatstaf, lyfstraf op 'n gebalanseerde wyse sal toepas.

\section{Strategieë vir sosio-emosionele vaardigheidsontwikkeling}

Cole et al. (2008) meen dat baie ouers, benewens kennis oor kinderopvoeding, ook inligting en inoefening van effektiewe, ontwikkelingsgeskikte strategieë nodig het sodat sosio-emosionele leer by hulle kinders kan plaasvind. Hierdie navorsers evalueer ' $n$ program vir die ontwikkeling van sosio-emosionele regulering en verwys na die rol van die ouer daarin. Hulle meen dat daar ouers is wat welmenend maar oneffektief in hulle leiding aan hulle kinders kan wees.

Wanneer ouers jong kinders wil ondersteun in die verstaan en beheer van hulle emosies, moet daar nie net empatiese verdraagsaamheid van die emosie, byvoorbeeld woede, wees nie. Ouers moet ook die geleentheid benut om die kinders te leer om die emosie te herken ('ek kan sien jy is nou baie kwaad'), te verstaan ('want jou karretjie is weg') en die beste strategie te kies om dit te reguleer ('wat sal die beste plan wees: jy kan skree, of op die vloer lê en skop, of dalk iemand vra om jou te help soek'). Verder moet jong kinders aangemoedig word om aan alternatiewe te dink indien die eerste poging nie slaag nie. Die navorsers wys daarop dat die ouers nie namens die kinders moet ingryp in die emosioneeluitdagende situasie wat hanteer moet word nie, aangesien vaardighede dan nie ontwikkel word nie. Aan die ander kant kan die ouers sonder warmte en verdraagsaamheid vir die woede skerp reageer en bloot alternatiewe optrede eis. In so 'n geval word die kinders van 'n geleentheid ontneem om sosio-emosionele vaardighede aan te leer of te verfyn.

Dit is belangrik om daarop te let dat ouers nie van kinders kan verwag om vaardighede in die sosiale en emosionele domeine te toon wat die ouer nie vir hulle (oor tyd) aangeleer het nie. Die bereiking van die ontwikkelingsuitkoms (Bronfenbrenner), naamlik meer gedissiplineerde optrede, neem tyd en moet as 'n proses beskou word.

Tardiff (2012:17) meen dat daar in ouervaardigheidsprogramme op ouers se sterk punte klem gelê moet word, 
eerder as om hulle te blameer. Die selfeffektiwiteit van ouers moet bevorder word en Sanders et al. (2008) toon aan dat die kernbeginsels van positiewe ouerskap ouers kan bemagtig. Hierdie kernbeginsels is die volgende: verseker 'n veilige, interessante omgewing; skep 'n positiewe omgewing waarin die kind kan leer; pas gesagsbepalende dissipline toe; koester realistiese verwagtings en sorg vir jouself as ouer.

Vanuit Bronfenbrenner se teorie kan die volgende afgelei word. Daar kan verwag word dat die invloed van dissiplineringstrategieë (proksimale prosesse) op sosioemosionele vaardighede (ontwikkelingsuitkoms) sal varieer volgens die eienskappe van die ouers en die kinders (persoon) binne ' $n$ bepaalde omgewing (konteks).

\section{Empiriese ondersoek Navorsingsontwerp}

Die navorsingsontwerp sluit die belangrikste aspekte van die navorsingstrategie, dataverwerking en navorsingsinstrument in en word vervolgens bespreek.

\section{Paradigma en navorsingstrategie}

Die navorsingsparadigma van hierdie navorsing is die pragmatiese wêreldbeskouing wat gepaard gaan met die gemengde metode-navorsingstrategie waarin daar van sowel kwalitatiewe as kwantitatiewe benaderings gebruik gemaak is ten einde ' $n$ verryking van inligting te verkry.

Die navorsingstrategie wat in hierdie navorsing gevolg word, is die gelyklopende ingebedde gemengde strategie (concurrent embedded strategy) wat impliseer dat daar van kwantitatiewe én kwalitatiewe benaderings gebruik gemaak is (Creswell 2009:214). In die onderhawige navorsing word die kwalitatiewe benadering binne die raamwerk van die kwantitatiewe benadering ingebed of opgeneem.

\section{Populasie en steekproefneming}

Die populasie bestaan uit 604 responderende ouers van kinders (47.3\% seuntjies en $50.7 \%$ dogtertjies) wat almal 5 of 6 jaar oud is en waarvan $33.2 \%$ in graad R-klasse is, terwyl $18.7 \%$ van die kinders in privaat-preprimêre skole was, en $45.5 \%$ in kleuterskole of speelgroepies was.

Die demografiese verspreiding van die respondente was soos volg: $45.7 \%$ was van Gauteng, $26.5 \%$ van Noordwes, $16.1 \%$ van die Vrystaat, 9.6\% van Limpopo en $0.3 \%$ van die OosKaap. Met betrekking tot woongebiede was $46 \%$ van hulle in 'n stad woonagtig, $27 \%$ in 'n groot dorp, $16.4 \%$ in 'n klein dorpie en $8 \%$ in 'n township of informele vestiging.

Maandelikse gesamentlike verdienste van die responderende gesinne was soos volg versprei: $2.4 \%$ van die huishoudings het gesamentlik R1000 of minder per maand verdien, $7.5 \%$ tussen R1000 en R5000, 14.3\% tussen R5000 en R10 000, 28.5\% tussen R10 000 en R20 000, 29.6\% tussen R20 000 en R40 000 en $14.3 \%$ meer as R40 000 per maand.

'n Gerieflikheidsteekproef (Patton 2002:243) is uit bogenoemde populasie saamgestel van beskikbare ouers binne die omgewing van die takke van Vroue in Aksie. ${ }^{1}$ Hierdie nasionale vroue-organisasie het landswyd die vraelyste aan beskikbare, gewillige ouers $(n=523)$ in hulle omgewing oorhandig vir voltooiing. Geen vereistes rakende ouderdom, geslag of ras van die respondente is gestel nie.

\section{Navorsingsinstrument}

Getrou aan die aard van die kwantitatiewe benadering is van 'n gestruktureerde, geslote vraelys gebruik gemaak. Met die oog op die verkryging van kwalitatiewe inligting is enkele oopeinde vrae ook ingevoeg (ingebed) ten einde die kwantitatiewe inligting te verryk.

\section{Dataversameling}

Die takverteenwoordigers van Vroue in Aksie het die vraelyste onder hulle beheer geneem nadat dit van die onderskeie takke ontvang is. Die navorsers het alle persone wat vraelyste uitgedeel en weer versamel het met behulp van 'n inligtingstuk volledig ingelig rakende die prosedure wat gevolg moes word voordat die vraelyste uitgedeel en weer versamel is. Hierdeur is verseker dat die prosedure oral op dieselfde wyse uitgevoer is. Ouers het saam met die vraelys 'n brief met inligting rakende die doel en aard van die navorsing ontvang, asook 'n vorm wat ingevul moes word om ingeligte toestemming te verseker.

\section{Statistiese tegnieke en dataverwerking}

Die statistiese dataverwerkingseenheid van die Statistiese hulpsentrum van die Noordwes-Universiteit het die statistiese verwerking met behulp van die SSPS-program gedoen (Field 2005). Beskrywende statistiek is verkry ten einde frekwensies en rangordes te bepaal. Inferensiële statistiek is verkry deur van Verimax-faktoranalise gebruik te maak (Field 2005:617). Met behulp van faktoranalise kon die kwalitatiewe data wat uit die oop items op die vraelyste verkry is, tematies gegroepeer word om dit by die kwantitatiewe bevindings in te pas (imbedding) (Creswell 2009:214; Oosthuizen \& Rossouw 2009:84).

Met behulp van die Cronbach-alpha-koëffisiënt as inferensiële statistiese tegniek, kon die betroubaarheid van die meetinstrument bepaal word.

\section{Betroubaarheid en geldigheid}

Gesigsgeldigheid blyk uit die feit dat al die vrae in die vraelys ooglopend op die hantering van kleinkinderdissipline fokus. Die geldigheid van die vraelys is verder ook verseker deur dit vooraf aan akademiese eweknieë vir inspraak voor te lê.

Die Cronbach-alpha-koëffisiënt is gebruik om die interne betroubaarheid van die meetinstrument te bepaal. 'n Cronbach-alpha-koëffisiënt van 0.762 is aangetoon, waaruit afgelei word dat die betroubaarheid aanvaarbaar is (Field 2005:674). Die mate van ooreenkomste in responsuitkomste uit die vraelyste dui op die toets-hertoetsbetroubaarheid van die meetinstrument.

1.Vroue in Aksie is 'n nasionale vroue-organisasie en funksioneer onder Solidariteit Helpende Hand, 'n artikel 21-maatskappy sonder winsbejag. 


\section{Etiese oorwegings}

Die ingeligte toestemming van gewillige respondente is verkry voordat die vraelyste ingevul is. Die vertroulikheid en anonimiteit van respondente is verseker en bevorder deurdat die voltooide vraelyste in 'n koevert geplaas, verseël en aan die navorsers besorg is. Deelname aan die navorsing was vrywillig en die respondente kon deelname te eniger tyd staak indien hulle dit verkies het. Etiese klaring is van die etiekkomitee van die Universiteit onder wie se toesig die navorsing gedoen is, verkry voordat die navorsing 'n aanvang geneem het.

\section{Bevindings}

In aansluiting by die doel van die navorsing, word die bevindings onder drie onderwerpe bespreek, naamlik kindergedrag wat ouers as problematies beskou, dissiplineringstrategieë wat ouers aanwend en ondersteuning vir dissiplinering.

\section{Problematiese gedrag}

In hierdie afdeling is nie voorbeelde van kindergedrag wat tot dissiplinêre probleme lei in die vraelys aangebied nie. Ouers is versoek om gedrag te beskryf wat hulle as problematies ervaar. Talle voorbeelde van ongewenste gedrag is beskryf, byvoorbeeld traagheid en weiering om opdragte uit te voer, leuens, woede-uitbarstings, vloerstuipe wanneer versoeke nie toegestaan word nie, traagheid om op te ruim, fisiese en verbale aggressie en die afknou van sibbe.

Ongehoorsaamheid en 'my kind luister nie' was die algemeenste vorm van ongewenste gedrag. Hoewel gedrag wat ouers as ongehoorsaamheid beleef verskillende oorsake kan hê, het ouers in die kwalitatiewe inligting self na oorsake verwys, byvoorbeeld 'ek en my man stem nie saam oor die reëls nie' en 'miskien is dit omdat ek onseker is'.

Ouers het ook die effek van ongewenste gedrag gerapporteer en moedeloosheid, woede ('ek word van my kop af kwaad as my kind dit doen'), die ervaring van onbevoegdheid as ouer ('ek voel ek faal as ouer') en frustrasie wanneer hulle kind gedrag openbaar wat tot dissiplinêre probleme lei, uitgelig. Hoewel die vraelys dit nie vereis het nie, is eienskappe van die kind, byvoorbeeld ADHD (aandagafleibaarheidshiperaktiwiteitsindroom), teruggetrokkenheid, 'moeilike geaardheid' en 'impulsief' ook genoem om gedrag te kwalifiseer. Eienskappe van die ouer is ook genoem ('ek is 'n haastige mens', 'ek wil dinge gou en reg gedoen hê'), asook breër omstandighede soos enkelouerskap en werksverpligtings wat deel van die konteks uitmaak. Hierdie inligting sluit aan by Bronfenbrenner se teorie dat die konteks en persoon-element dissiplinering kan beïnvloed.

\section{Dissiplineringstrategieë}

Elf moontlike opsies rakende die strategieë wat ouers aanwend om hulle kinders se gedrag te dissiplineer, is op grond van die ontleding van die vraelyste in ' $n$ rangorde geplaas. Ouers moes op 'n vierpuntskaal aantoon of hulle die strategie beslis, onwaarskynlik, waarskynlik of heel waarskynlik sal toepas (kyk Tabel 1).

Uit Tabel 1 blyk die responderende ouers se positiewe aanslag tot dissiplinering. Die strategie beloning van goeie gedrag is as die mees gebruikte uitgewys. Dit sluit aan by die elemente van positiewe ouerskap (Tardiff 2012:15), is 'n bevestiging van Rogers (2006) se standpunt rakende 'n positiewe benadering tot die hantering van dissipline onder skoolkinders en sluit aan by die Christelike benadering van erkenning. Verder kan beloning vir goeie keuses in optrede sosio-emosionele vaardigheidsontwikkeling versterk.

Ouers het die volgende vergeldende benaderings as minder aanvaarbaar aangetoon deur dit onderaan die ranglys te plaas: die toediening van lyfstraf, die plasing van die kind wat oortree in 'n ander kamer, die wegstuur van die kind na 'n ander familielid en optrede wat die kind se skuldgevoelens aktiveer. Lyfstraf is egter in die kwalitatiewe inligting deur verskeie ouers, van wie die meeste aangedui het dat hulle die Christelike lewensbeskouing huldig, sterk ondersteun.

Ouers toon aan dat hulle hul manier van dissipline verander om by die situasie aan te pas en dat hulle buigsaam is. Hoewel buigsaamheid ruimte laat vir onderhandeling oor gedrag (Firmin \& Castle 2008:119) en interpretasie van die omstandighede, kan oormatige buigsaamheid onsekerheid meebring en sosio-emosionele vaardigheidsontwikkeling teenwerk. Buigsaamheid in die dissiplinesituasie sou kon beteken dat ouers nie konsekwent is nie, of dat hulle buigsaamheid ' $n$ toegee aan die gedrag kan wees wat die ouer eintlik nie aanvaar nie. Die permissiewe ouerskapstyl word onder andere gekenmerk deur inkonsekwente terugvoer oor gedrag, terwyl die gesagsbepalende ouerskapstyl duidelikheid en konsekwentheid daarstel (Louw \& Louw 2007:194). Verskeie ouers het in die oop ruimte by hierdie afdeling aangedui dat konsekwentheid 'n suksesvolle dissiplineringstrategie is en dat dit aansluit by die vaste norme van die Bybel.

Op die opsie: 'Ek leer die kind hoe om spesifieke situasies te hanteer' (coping skills) het $85.2 \%$ van die ouers positief gerespondeer. In die kwalitatiewe inligting het ouers stategieë beskryf hoe hulle die kinders lei, byvoorbeeld: 'ek laat hom

TABEL 1: Ouermenings oor dissiplineringstrategieë.

\begin{tabular}{|c|c|c|c|}
\hline Nommer & Vraag & $\%$ respons & Rangorde \\
\hline 11 & Ek beloon die kind vir goeie gedrag & 87.6 & 1 \\
\hline 13 & $\begin{array}{l}\text { Ek leer kind hoe om spesifieke situasies te hanteer } \\
\text { (coping skills) }\end{array}$ & 85.2 & 2 \\
\hline 18 & $\begin{array}{l}\text { Ek herinner kind aan die reël en vereis dadelik } \\
\text { gehoorsaamheid }\end{array}$ & 84.1 & 3 \\
\hline 14 & $\begin{array}{l}\text { Ek verander my manier van dissipline om by die } \\
\text { situasie te pas }\end{array}$ & 77.2 & 4 \\
\hline 10 & Ek dreig die kind ('as jy weer ... sal ek ...') & 56.2 & 5 \\
\hline 8 & Ek onderhandel oor gedrag & 50.7 & 6 \\
\hline 9 & Ek preek vir die kind & 48.3 & 7 \\
\hline 16 & Ek pas lyfstraf toe & 44.7 & 8 \\
\hline 17 & Ek laat die kind skuldig voel oor verkeerde optrede & 39.3 & 9 \\
\hline 15 & Ek laat kind in ander kamer sit & 37.2 & 10 \\
\hline 12 & Stuur kind na ander familielid & 6.2 & 11 \\
\hline
\end{tabular}


my opdrag herhaal sodat hy kan konsentreer en onthou', 'ek laat haar op die stoutstoeltjie sit' en 'ek vat voorregte weg soos om saam met my dorp toe te gaan'. Beskrywings van die aanleer van sosio-emosionele vaardighede, byvoorbeeld hoe om in spesifieke situasies op te tree soos wanneer 'n maat 'n speelding vat en die kind kwaad word, het grootliks ontbreek. Voorbeelde van alternatiewe strategieë (wat nie in die vraelys voorgekom het nie) het meestal maatreëls betrek waardeur ouers skynbaar hulle kinders wil beheer en beskrywings van die herkenning van emosies en die uitoefen van keuses oor gewenste gedrag, het ook ontbreek. Dit is ook moontlik dat ouers die idee van vaardigheidsontwikkeling by die kind ondersteun, maar nie seker is hoe om vaardighede aan te leer nie. Twee respondente se opmerkings in hierdie verband was: 'Ek sal raad waardeer' en 'Please help, I am lost' [Help asseblief, ek is verlore].

\section{Hoe ouers ondersteun kan word}

In een van die onderafdelings aangetoon in Tabel 1 , het die responderende ouers die geleentheid gehad om hulle menings te gee oor die moontlike wyses waarop bystand aan ouers gegee kan word rakende die dissiplinehantering met die skool as spilpunt (kyk Tabel 2).

In hierdie afdeling was die konstrukgeldigheid aanvaarbaar, aangesien slegs ' $n$ enkele faktor onttrek en geanaliseer is waar die betrokke ses vrae 'n hoë eigen-waarde van 2.755 en 'n variansiepersentasie van 45.913 vertoon (vgl. Tabel 2). Vervolgens het die Cronbach-alpha-koëffisiënt van 0.762 die aanvaarbare betroubaarheid aangetoon (kyk Tabel 3).

Een moontlike respons handel oor praatjies by die skool oor dissipline. Hier word nie aangedui watter instansie of spreker vir die praatjie verantwoordelik was nie. Van die ouers uit al die inkomstegroepe het $65.7 \%$ hierdie moontlikheid as die mees gewenste ondersteuningsmeganisme beskou. Die literatuur bewys egter dat die ouers wat die inligting die meeste nodig het, dikwels nie van sulke geleenthede gebruik maak nie (Sheridan et al. 2010:145-146). Gesinsomstandighede soos vervoerprobleme en praktiese probleme soos dat daar niemand is om na die kinders om te sien nie, kan tot hierdie verskynsel bydra. Een respondent het in die kwalitatiewe rubriek aangedui: '[W]ie kyk na my kinders as ek in die aand moet skool toe gaan?' Dit is ook moontlik dat daar ouers kan wees wat nie besef dat hulle by inligting rakende dissipline en ouerskapsvaardighede kan baat nie.

\begin{tabular}{|c|c|c|c|}
\hline Nommer & Vraag & $\%$ respons & Rangorde \\
\hline 20 & Praatjies by die skool oor dissipline & 65.7 & 1 \\
\hline 23 & Praktiese wenke vanaf onderwyser & 60.2 & 2 \\
\hline 24 & $\begin{array}{l}\text { Werkswinkels oor dissipline deur iemand anders } \\
\text { as die skool }\end{array}$ & 58.3 & 3 \\
\hline 22 & Ondersteuningsgroepe vir ouers & 46.5 & 4 \\
\hline 21 & Uitdeel van pamflette oor dissipline & 39.6 & 5 \\
\hline 19 & Onderwysers se besoeke by huis & 9.5 & 6 \\
\hline
\end{tabular}

TABEL 3: Faktoranalise en betroubaarheid.

\begin{tabular}{lll}
\hline Vrae & Variansie (\%) & Cronbach-alpha-koëffisiënt \\
\hline $19,20,21,22,23,24$ & 45.913 & 0.762 \\
\hline
\end{tabular}

Praktiese wenke wat deur die onderwyser huis toe gestuur word, is as 'n verdere moontlike respons aangedui. Van die ouers het $60.2 \%$ sulke wenke as die mees gewenste strategie aangewys. Aangesien die onderwyser daagliks met die kinders te doen het en waarnemings in die ouers se afwesigheid doen, is sy in die beste posisie om aan te toon watter leemtes daar by die kinders mag bestaan of watter gedrag positief versterk moet word. Gereelde terugvoer bevorder kommunikasie tussen die ouers en die onderwyser en wenke bied 'n aanknopingspunt vir die gesprek. Een deelnemer het voorgestel dat die onderwyser leiding oor ontwikkelingsgeskikte huisreëls moet gee, 'want dan hoef pa en ma nie daaroor te verskil nie'.

Ouers vir wie waardes en beginsels rakende kinderopvoeding baie belangrik is en wat wil toesien dat daar op hierdie beginsels voortgebou word, verwag gereelde terugvoer van die onderwyser sodat daar saam oor leiding aan die kinders besin kan word. 'n Voorwaarde is egter dat die ouers en die skool dieselfde beginsels moet handhaaf. 'Daar moet dieselfde verwagtings van die kind by die skool wees, anders verwar ons hom', was een ouer se opmerking.

Die opsie, 'onderwyser se besoeke by die huis', is nie deur ouers ondersteun nie. Ouers kon tuisbesoeke as 'n moontlike strategie om ouers met dissipline te help, op twee wyses geïnterpreteer het: eerstens dat tuisbesoeke deur opvoeders nie plaasvind nie en tweedens dat tuisbesoeke nie as 'n effektiewe metode beskou word om ouers te help met die dissiplinering van hulle kinders nie. Daar sou ook afgelei kon word dat daar nie 'n behoefte aan ouerbesoeke bestaan nie, omdat die ouers hulle privaatheid hoog ag of nie die inspraak deur die opvoeder as waardevol beskou nie. Die literatuur toon egter dat die effek van ouerleidingsprogramme van korte duur is indien die samewerking tussen die ouers en die opvoeder ontbreek (Herrera \& Little 2005:80). Die invloed van Bronfenbrenner se mesosisteem word hiermee beklemtoon.

Die wenslikheid van werkswinkels oor dissipline wat deur iemand anders as die skoolpersoneel aangebied word, is ook as ' $n$ moontlike strategie aangebied en is deur $58.3 \%$ van die ouers ondersteun. Dit kan soos volg geïnterpreteer word: die ouers sal uiteraard eerder werkswinkels, aangebied deur spesialiste oor kinderopvoeding, bywoon. Daar mag egter ook ouers wees wie se vertroue in die onderwyser geskaad is en om daardie rede persone van buite die skool se mening verkies. 'n Respondent verduidelik, met verwysing na die onderwyser: '[S]y praat met my oor my kind voor ander mense'.

Minder as die helfte van die ouers het ondersteuningsgroepe vir ouers verkies. Hoewel ondersteuningsgroepe waardevol mag wees, verg dit beplanning en tyd. Baie ouers toon aan dat die lewenstempo veeleisend is en daar kan afgelei word dat hierdie opsie nie alle huishoudings sal pas nie. Een ouer rapporteer in die kwalitatiewe inligting: '[O]ns het ' $n$ enkelouergroepie wat my baie help'.

Geskrewe inligting soos pamflette bereik baie ouers van jong kinders via die skool. Van die ouers het $39.6 \%$ hierdie 
opsie gekies, waarskynlik omdat hulle die inligting tuis kan lees wanneer dit hulle pas. Wanneer die ouers nie daagliks die kinders se skooltassies nagaan of die kinders nie oor die pamflet praat nie, mag inligting op pamflette egter verlore gaan.

In die kwalitatiewe inligting het ouers aangedui dat hulle die leiding van die skool waardeer, maar dat hulle ook gebruik maak van internetbronne, televisieprogramme soos Dr Phil, ouerleidingprogramme soos Immergroen ouerskap deur Hettie Brittz, Manners 4 Minors asook van professionele ondersteuning deur terapeute. Ouers het ook voorstelle rakende die breër ondersteuning aan ouers en voornemende ouers gemaak. Dit sluit in staatsondersteunde ouerskapsklasse, 'n verpligte wetenskaplik-gebaseerde kurrikulum vir dagmoeders en kleuterskole en ouerskapsvoorbereiding as deel van die vak Lewensvaardighede vir senior leerders.

\section{Bespreking}

Die doel van die navorsing was om ondersoek in te stel na die gedrag van vyf- tot sesjarige kinders wat deur hulle ouers as problematies ervaar word, die effek van die gedrag op ouers, die strategieë wat ouers toepas om leiding in hierdie verband te gee en die aard van die ondersteuning wat ouers verkies.

Responderende ouers ervaar nie net verskillende vorms van ongewenste gedrag soos aggressie, ongehoorsaamheid, leuens, afknouery en woede-uitbarstings wat tot dissiplinêre probleme tuis lei nie, maar ook die negatiewe invloed van die gedrag op hulle eie emosionele lewe sowel as op dié van ander gesinslede (Pearl 2009:296). Eienskappe van die kind soos 'n moeilike geaardheid sowel as dié van die ouer soos 'n haastige persoon wat dinge vinnig wil afhandel en ook die breër konteks waarin die gesin woon, kan die aanleer van sosio-emosionele vaardighede beïnvloed. Bronfenbrenner se persoon- en konteks-dimensies word hierdeur onderstreep. Die proksimale proses, naamlik dissiplinering, het in hierdie navorsing prioriteit geniet.

Die beloning van goeie gedrag as die mees gebruikte dissiplineringstrategie is ' $n$ aanduiding dat ouers oorwegend 'n positiewe benadering in dissiplinering wil volg. Hulle toon ook buigsaamheid deurdat hulle hulle strategie by die situasie aanpas. Oormatige buigsaamheid mag egter tot inkonsekwentheid lei wat weer onsekerheid by kinders skep. 'n Gesagsbepalende ouerskapstyl word, in teenstelling hiermee, gekenmerk deur duidelikheid en konsekwentheid (Louw \& Louw 2007). Die doelbewuste aanleer van sosioemosionele vaardighede soos die herkenning van en begrip vir emosies en die uitoefen van die beste keuse rakende gedrag (Denham et al. 2012:248) skyn egter in 'n groot mate te ontbreek en kan moontlik ' $n$ aanduiding wees dat ouers onkundig is oor hoe om op hierdie gebied leiding te gee. Ouers toon ook aan dat hulle ondersteuning rakende dissiplinering van hulle kinders sal waardeer.

Die bywoning van praatjies by die skool en werkswinkels wat deur ander persone aangebied word, is die voorkeurwyses waarop ouers verkies om ingelig te word rakende dissiplinering. Ouerondersteuningsgroepe en pamflette waardeur inligting aan ouers deurgegee word, word deur minder ouers ondersteun, terwyl tuisbesoeke baie min ondersteuning geniet. Dit wil dus voorkom asof die ouers wel die skool se kundigheid oor die hantering van kindergedrag erken, maar ook van terapeute, kommersiële ouerleidingsprogramme en die internet gebruik maak. 'n Verskeidenheid ondersteuningstrategieë, wat op navorsing gebaseer moet wees, sal derhalwe wenslik wees indien ouerleidingsprogramme vir Suid-Afrikaanse ouers saamgestel word.

Verder sal ouerleidingsprogramme wat alle ouers van vyftot sesjarige kinders insluit, voordelig wees, aangesien die literatuur bevestig dat dissiplinêre probleme nie beperk is tot 'n sekere deel van die bevolking nie (McCain et al. 2007). Ouerskapsvaardighede moet, net soos die verfyning van ander vaardighede, deur middel van relevante kennis en inoefening bemeester word, onder leiding van toepaslik opgeleide persone.

\section{Bydrae van die studie}

Hierdie studie bevestig dat ouers ' $n$ behoefte aan leiding het rakende die dissiplinering van hulle kinders en spesifiek ten opsigte van sosiaal-emosionele vaardigheidsontwikkeling. Die bevindings van die navorsing kan rigtinggewende insigte verskaf aan enige organisasie of skool wat sodanige ouerleidingsprogramme wil ontwikkel. 'n Belangrike uitvloeisel van die aanbied van ouerleidingsprogramme kan die verbetering van die vennootskap tussen die ouers en die onderwysers tot gevolg hê en op die persoonlike vlak beter leeruitkomste en potensiaalrealisering teweeg bring.

\section{Slotopmerking}

Die vroeë dissiplinering van kinders is nie net van kritieke belang vir die benutting van programme wat voorskools aangebied word nie (Chen 2008:472), maar ook vir die realisering van kinders se potensiaal in die algemeen. Die ontwikkeling van sosio-emosionele vaardighede vorm deel van dissiplinering en baie ouers skyn onkundig te wees oor hoe om hulle kinders te lei in die regulering van emosies en besluitneming oor aanvaarbare gedrag (Denham et al. 2012). Ouers ervaar dus dissiplinêre uitdagings in die opvoeding van hulle kinders en het daarom 'n behoefte aan ondersteuning.

Hoewel die skool nie die enigste bron van ondersteuning is nie, kan die samewerking tussen die huis en die skool tot gesonde dissipline bydra. Ouers verkies verskillende vorms van ondersteuning, waaronder praatjies by die skool, praktiese wenke vanaf die onderwyser, werkswinkels, pamflette met inligting en ondersteuningsgroepe. Om sinvolle ondersteuning te bied, moet die skool die invloed van die eienskappe van die persone wat betrokke is, die konteks waarin hulle lewe en die aard van die interaksie tussen ouers, kinders en onderwysers (Bronfenbrenner) in ag neem. Christelike norme wat prakties na vore kom in modellering deur die emosioneel-belangrike volwassene en die skep van 'n liefdevolle huisomgewing, kan 'n verdere basis vir dissiplinering bied. 


\section{Erkenning}

Die projek is onder leiding van professor J.P. Rossouw uitgevoer.

\section{Mededingende belange}

Die outeurs verklaar dat hulle geen finansiële of persoonlike verbintenis het met enige party wat hulle nadelig of voordelig kon beïnvloed het in die skryf van hierdie artikel nie.

\section{Outeurbydraes}

M.C.R. (Noordwes-Universiteit) was verantwoordelik vir die projekontwerp, insameling van data en ontleding van kwalitatiewe data. I.J.O. (Noordwes-Universiteit) was verantwoordelik vir statistiese ontleding van data.

\section{Literatuurverwysings}

Ackerman, B.P., Kogosd, J., Youngstrom, E., Schoff, K. \& Izard, C., 1999, 'Family instability and the problem behaviors of children from economically disadvantaged families' [Gesinsonstabiliteit en die probleemgedrag van kinders uit ekonomiesbenadeelde gesinne], Developmental Psychology 35, 258-268. http://dx.doi. org/10.1037/0012-1649.35.1.258, PMid:9923480

Afrikaanse Reformatoriese Skoolonderwys (ARSO), 2002, Dit is gereformeerde onderwys: Gereformeerde vakbenaderings, ARSO, Pretoria.

Alegre, A., 2011, 'Parenting styles and children's emotional intelligence: What do we know?' [Ouerskapstyle en kinders se emosionele intelligensie: Wat weet ons?]
The Family Journal 19(1), 56-62. http://dx.doi.org/10.1177/1066480710387486

Baumrind, D.,1971, 'Current patterns of parental authority' [Huidige patrone van ouerlike gesag], Developmental Psychology Monographs 4(1, Pt. 2), 1-103. http:// dx.doi.org/10.1037/h0030372

Brittz, H., 2009, 'Creative ideas for parents', in Evergreen parenting, viewed 24 September 2012, from http://www.evergreenparenting.co.za

Bronfenbrenner, U. \& Morris, P.A., 1998, 'The ecology of developmental processes', in W. Damon \& R.M. Lerner (eds.), Handbook of child psychology, vol. 1, Theoretical models of human development, 5th edn., pp. 993-1023, Wiley, New York.

Bronfenbrenner, U. \& Morris, P.A., 2006, 'The bioecological model of human development', in W. Damon \& R.M. Lerner (eds.), Handbook of child psychology, vol. 1, Theoretical models of human development, 6th edn., pp. 793-828, Wiley, New York.

Chen, J.J-L., 2008, 'Gender differences in externalising problems among preschool children: Implications for early childhood educators' [Geslagsverskille in eksternalisering van probleme onder voorskoolse kinders: Implikasies vir vroee kinderjare opvoeders], Early Child Development and Care 180(4), 469-474.

Cole, P.M., Dennis, T.A., Smith-Simon, K.E. \& Cohen, L.H., 2008, 'Preschooler's emotion regulation strategy understanding: Relations with emotion socialisation and child self-regulation' [Die voorskoolse kind se begrip van emosie-reguleringstrategie: Verbande met emosionele sosialisering en kind-selfregulering], Social Developmen 18(2), 324-352. http://dx.doi.org/10.1111/j.1467-9507.2008.00503.x

Cowen, P.S., 2001, 'Effectiveness of a parent education intervention for at-risk families' [Doeltreffendheid van ' $n$ ouer se opvoedkundige intervensie vir kwesbare gesinne], Journal of the Society of Pediatric Nurses 6(2), 73-82. http://dx.doi. org/10.1111/j.1744-6155.2001.tb00124.x, PMid:11326464

Creswell, J.W., 2009, Research design, Sage, Los Angeles.

Davin, R. \& Van Staden, C., 2005, The reception year: Learning through play, 2nd edn., Heinemann, Johannesburg. PMCid:PMC1798210

Denham, S.A., Bassett, H.H., Thayer, S.K., Mincic, M.S., Sirotkin, Y.S. \& Zinsser, K., 2012 'Observing preschooler's social-emotional behavior: Structure, foundations, and prediction of early school success' [Waarneming van 'n voorskoolse kind se sosiaalemosionele gedrag: struktuur, fondasies en voorspelling van sukses tydens vroeë skooljare], The Journal of Genetic Psychology 173(3), 246-278. http://dx.doi.org/ 10.1080/00221325.2011.597457, PMid:22919891

Duncan, G. \& Brooks-Gunn, J., 1997, Consequences of growing up poor, Russell Sage Foundation, New York.
Field, A., 2005, Discovering statistics using SPSS, Sage, London.

Firmin, M.W. \& Castle, S.L., 2008, 'Early childhood discipline: A review of the literature' [Vroeë kinderjare dissipline: 'n Oorsig van die literatuur], Journal of Research on Christian Education 17, 107-129. http://dx.doi.org/10.1080/10656210801909715

Herrera, M. \& Little, E., 2005, 'Behaviour problems across home and kindergarten in an Australian sample' [Gedragsprobleme oor die huis en kleuterskool heen in ' $n$ Australiese geval], Australian Journal of Educational \& Developmental Psychology 5, 77-90.

Jewell, J.D. \& Stark, K.D., 2003, 'Comparing the family environments of adolescents with conduct misorder or depression' ['n Vergelyking van die gesinsomgewings van adolessente met gedragsversteurings of depressie], Journal of Child and Family Studies 12, 77-89. http://dx.doi.org/10.1023/A:1021310226400

Joachim, S., Sanders, M.R. \& Turner, K.M.T., 2010, 'Reducing preschoolers' disruptive behavior in public with a brief parent discussion group' [Die vermindering van kleuters se ontwrigtende gedrag in die openbaar deur ' $\mathrm{n}$ kort bespreking-ouergroep], Child Psychiatry Human Development 41, 47-60. http://dx.doi.org/10.1007/s10578-0090151-z, PMid:18793067

Joubert, R. \& Serekwane, J., 2009, 'Establishing discipline in the contemporary classroom' [Vestiging van dissipline in die hedendaagse klaskamer], Journal of Educational Studies 8, 125-137.

Keating, J.B. \& Rossouw, J.P., 2009, 'The influence of ill-disciplined learners on the workplace security of the foundation phase educator in South Africa' [Die invloed van swak gedissiplineerde leerders op die werkplek sekuriteit van die grondslagfaseonderwyser in Suid-Afrika], Journal of Educational Studies 8(2), 128-139.

Landry, S.H., Smith, K.E., Swank, P.R., Assel, M.A. \& Vellet, S., 2001, 'Does early responsive parenting have a special importance for children's development or is consistency in early childhood necessary?' [Is vroeë reaskie-ouerskap van spesiale consistency in early childhood necessary?' Is vroee reaskie-ouerskap van spesiale
belang vir kinders se ontwikkeling of is konsekwentheid in die vroeë kinderjare belang vir kinders se ontwikkeling of is konsekwe
nodig?], Develomental Psychology 44, 1335-1353.

Louw, D. \& Louw, A., 2007, Die ontwikkeling van die kind en adolessent, Psychology Publications, Bloemfontein.

Maxwell, J.C., 2007, The Maxwell leadership Bible, Thomas Nelson, Nashville.

McCain, M.N., Mustard, J.F. \& Shanker, S., 2007, Early Years Study, vol. 2, Putting science into action, Council for Early Childhood Development, Toronto.

Oosthuizen, I.J., 2006, Praktiese wenke vir leerderdissipline, Van Schaik, Pretoria.

Oosthuizen, I.J. \& Rossouw, M.C., 2009, 'The phenomenon of swearing among South African learners' [Die verskynsel van vloek onder Suid-Afrikaanse leerders], Journal of Educational Studies 8(2), 74-90.

Patton, M.Q., 2002, Qualitative research \& evaluation methods, Sage, Thousand Oaks.

Pearl, E.S., 2009, 'Parent management training for reducing oppositional and aggressive behaviour in preschoolers' [Ouer-bestuursopleiding vir die vermindering van opposisionele en aggressiewe gedrag in voorskoolse kinders], Aggression and Violent Behavior 14, 295-305. http://dx.doi.org/10.1016/j.avb.2009.03.007

Rogers, B., 2006, Classroom behaviour: A practical guide to effective teaching, behaviour management and colleague support, 2nd edn., Paul Chapman, London.

Russell, C., Birnbaum, N., Avison, W.R. \& loannone, P., 2011, 'Vital Support: How well do Canada's communities support parents of young children?, Phase 2, Report: What parents tell us', in The Phoenix centre for children \& families, viewed 14 October 2012, from http://www.phoenixpembroke.com

Sanders, M.R., Ralph, A., Sofronoff, K., Gardiner, P., 2008, 'Every family: A population approach to reducing behavioral and emotional problems in children making the transition to school' 'Elke gesin: 'n Populasie-benadering tot die vermindering van transition to school' [Elke gesin: 'n Populasie-benadering tot die vermindering van gedrags-en emosionele probleme by kinders wat die oorgang na skool maak], The
Journal of Primary Prevention 29(3), 197-222. http://dx.doi.org/10.1007/s10935Journal of Prim

Schulze, S. \& Dzivhani, M.D., 2002, 'The role of discipline in school and classroom: A case study in South Africa' [Die rol van dissipline in die skool en klaskamer: ' $n$ Gevallestudie in Suid-Afrika], Journal of Psychology 12(2), 119-130.

Sheridan, S.M., Knoche, L.L., Edwards, J., Bovaird, A. \& Kupzyl, K.A., 2010, 'Parent engagement and school readiness: Effects of the getting ready intervention on preschool children's social-emotional competences' [Ouerbetrokkenheid en skoolgereedheid: Gevolge van die gereedheidsingryping op voorskoolse kinders se sosiaal-emosionele bevoegdheid], Early Childhood \& Development 21(1), 125-156.

Tardiff, E., 2012, Positive parenting in Waterloo Region: Exploring a comprehensive approach, Final report, Region of Waterloo Public Health, Ontario.

Tudge, J.R.H., Mokrova, I., Harfield, B.E. \& Karnik, R.B., 2009, 'Uses and misuses of Bronfenbrenner's bioecological theory of human development' [Gebruike en misbruike van Bronfenbrenner se bio-ekologiese teorie van menslike ontwikkeling], Journal of Family Theory \& Review 1, 198-210. http://dx.doi.org/10.1111/j.17562589.2009.00026.x

Vogel, D., 2008, 'Parent involvement in learning as preventative factor against youth misbehavior' [Ouerbetrokkenheid in leer as voorkomende faktor teen jeugwangedrag], Acta Criminologica 21(2), 16-26. 